\title{
Cyanobacterial biodiversity and associated ecosystem services: introduction to the special issue
}

\author{
Anurag Chaurasia ${ }^{1}$
}

Published online: 14 March 2015

(C) Springer Science+Business Media Dordrecht 2015

Cyanobacteria, one of the oldest groups of known organisms, are photosynthetic prokaryotes. They have existed for about 3.5 billion years, from Pre-cambrian times, and played a significant role in oxygen accumulation in the Earth's early atmosphere making it fit for the survival of aerobic life-forms. Their unique ability, the ability to fix nitrogen and carry out oxygen-evolving photosynthesis and oxygen-labile nitrogen fixation within the same organisms, has always fascinated researchers (Mitsui et al. 1986). During their long evolutionary history, cyanobacteria have been able to adapt to geochemical and climate changes as well as anthropogenic disturbances (Paerl and Otten 2013). They probably exhibit the widest range of diversity in growth habitats of all photosynthetic organisms, and have developed $\mathrm{CO}_{2}$ concentrating mechanisms which adapt them to various environmental limitations (Badger et al. 2006). With an estimated global biomass of $3 \times 10^{14} \mathrm{~g} \mathrm{C}$, or $10^{15} \mathrm{~g}$ wet biomass (Garcia-Pichel et al. 2003), quantitatively they are also some of the world's most important organisms (Whitton 2012). Many of the species, however, remain to be discovered (Nabout et al. 2013), and cyanobacteria remain a neglected component of biodiversity research (Rejmankova et al. 2004).

Global warming will have a profound impact on cyanobacterial biodiversity, probably favouring them over other phytoplankton (Carey et al. 2012), increasing cyanobacterial blooms formation (Wagner and Adrian 2009), and also favour toxin producing species or elevated toxin concentration by extant species with severe consequences for associated ecosystem services (Kleinteich et al. 2012). Lake warming with reduced water turnover and a changed nutrient ratio too will also favour the growth of harmful filamentous cyanobacteria (Posch et al. 2012) and their dominance will affect ecosystem functioning and community turnover in nutrient-enriched lakes (Filstrup et al. 2014). As cyanobacteria have significant ecological roles, their biodiversity need to be fully explored and conserved

Anurag Chaurasia

anurag_vns1@yahoo.co.in

1 National Bureau of Agriculturally Important Microorganisms, Indian Council of Agricultural Research, Mau Nath Bhanjan 275103, Uttar Pradesh, India 
for the effective management of ecosystem dynamics under present climate change scenarios.

This special issue on cyanobacterial biodiversity comprises of 14 contributions, and has been compiled with the interests of macrobiologists in mind as most of the available publications on the group are addressed to microbiologists. In the first article, issue Sciuto and Moro (2015) discuss the bright and dark side of this important group of organisms; on one side they provide crucial ecological services (Díez and Ininbergs 2014), while on the other they produce a wide range of cyanotoxins which have been linked with climate change (Paerl and Paul 2012). Cyanobacterial biodiversity, phylogeny, and taxonomy too have remained paradoxical (Pinevich 2008). Cyanobacterial taxonomy still requires a consensus approach (Palinska and Surosz 2014) to realize the actual biodiversity status of this group. Scientific discussion on cyanobacterial nomenclature under the International Code of Nomenclature of Prokaryotes (ICNP), including those published under the International Code of Nomenclature for algae, fungi, and plants(ICN; formerly the International Code of Botanical Nomenclature, ICBN) is underway (Oren and Garrity 2014; Imhoff 2014; Pinevich 2014). An overview on cyanobacterial taxonomy, species concepts, and speciation factors having significant impact on their biodiversity status are elaborated by Dvořák et al. (2015). Unexplored biodiversity of terrestrial cyanobacteria present on natural and anthropogenic stone surfaces around the world, and their ecological significance, is reviewed by Hauer et al. (2015). Cyanobacteria can survive in certain extreme environments, and the biodiversity of those surviving in hypersaline environments, their adaptative mechanisms, and contribution to ecosystem maintenance, is reviewed by Oren (2015). The cyanobacterial biodiversity of mangrove ecosystems, with extreme or oligotrophic environmental conditions, has a significant ecological role, especially in term of $\mathrm{C}$ and $\mathrm{N}$ fixation and $\mathrm{P}$ accumulation, discussed by Alvarenga et al. (2015). Polar regions (Antarctica and the arctic) are well known for extreme environmental conditions which are too harsh for the survival of most life. Makhalanyane et al. (2015) describe the cyanobacterial biodiversity of these regions, their adaptative mechanisms, and the essential ecosystem services they provide, particularly as mediators of biogeochemical cycles. de los Ríos et al. (2015) present original research on the extent of cyanobacterial biodiversity in arctic lakes, ponds and streams which contribute significantly to total ecosystem biomass and productivity. Cantonati et al. (2015) compile information on the rich and peculiar cyanobacterial biodiversity of ambient springs, whose biodiversity been neglected so far. They make a significant contribution to the importance of spring cyanoprokaryotes in maintaining the ecological integrity, quality and natural protection of these habitats.

Cyanobacterial blooms and cyanotoxins production represent a dark side to this beautiful group of organisms, which are able to modify ecosystem processes through trophic cascades and geochemical cycles. Focusing on these issues, Sukenik et al. (2015) summarizes what we know of invasive cyanobacteria, cyanotoxins, and their ecological interactions. Cyanobacteria show varied morphological and physiological features under different ecologies and environments, and Mateo et al. (2015) discuss their role as environmental indicators and bioreporters in aquatic ecosystems. Further Carmela Caroppo (2015) describes how the ecology and biodiversity of planktonic picocyanobacteria of coastal and brackish environments has potential applications in ecosystem sustainability.

Cyanolichens, an obligate mutualistic symbiosis between fungi and cyanobacteria, represent an important biodiversity component of terrestrial ecosystems, making significant contributions of nitrogen budgets, and also serving as bioindicators of air quality and/or habitat continuity (Rikkinen 2015). Free-living and symbiotic nitrogen-fixing cyanobacteria also make substantial contribution to the global natural nitrogen budget in 
marine and terrestrial ecosystems. As cyanobacteria generally prefer higher water temperatures, they are predicted to benefit from global warming (Hense et al. 2013), but temperature is probably also the reason for the absence of nitrogen-fixing heterocystous cyanobacteria in tropical oceans (Stall et al. 2003). An important application is in the use of cyanobacterial bioinoculants in rice fields where they contribute in nitrogen fixation besides enhancing soil fertility. Das et al. (2015) present findings on cyanobacteria/pesticides/rice interactions and conclude that application of both herbicides and pesticides was not deteromental to cyanobacterial health, thus conserving their biodiversity in rice fields and leading to enhanced crop productivity.

How urbanization negatively affects cyanobacterial biodiversity, and in turn agricultural productivity, is addressed by Sharma (2015). He concludes that there is a need to strengthen studies in urban ecology and ecosystem processes, drawing attention to the potential use of cyanobacterial population dynamics and diversity in designing restoration strategies in peri-urban areas.

From the contributions presented in this Special Issue, it is evident that we are still far from realizing the real biodiversity of this most ancient group of organisms. This is especially so where a consensus on cyanobacterial taxonomy is needed, along with expertise in polyphasic approaches for the identification of those that can be cultured. This issue needs to be incorporated into future environmental and ecosystem assessments from the local to the global el level in view of their role in maintaining essential ecological processes-which will undoubtedly become more important under future climate change scenarios.

Acknowledgments I sincerely thank all the reviewers, the real players behind the scene, for their valuable comments in improving the quality and presentation of the papers included here. Thanks are also due to all the staff at Springer's editorial office, especially Renuka Nidhi, for timely cooperation. However the publication of this Special Issue could not have been realized without David L. Hawksworth, who saw this as timely and guided me through all stages of its preparation to final publication.

\section{References}

Alvarenga DO, Rigonato J, Branco LHZ, Fiore MF (2015) Cyanobacteria in mangrove ecosystems. Biodivers Conserv. doi:10.1007/s10531-015-0871-2

Badger MR, Price GD, Long BM, Woodger FJ (2006) The environmental plasticity and ecological genomics of the cyanobacterial $\mathrm{CO}_{2}$ concentrating mechanism. J Exp Bot 57:249-265

Cantonati M, Komárek J, Zurita GAM (2015) Cyanobacteria in ambient springs. Biodivers Conserv. doi:10. 1007/s10531-015-0884-X

Carey CC, Ibelings BW, Hoffmann EP, Hamilton DP, Brookes JD (2012) Eco-physiological adaptations that favour freshwater cyanobacteria in a changing climate. Water Res 46:1394-1407

Caroppo C (2015) Ecology and biodiversity of picoplanktonic cyanobacteria in coastal and brackish environments. Biodivers Conserv. doi:10.1007/s10531-015-0891-y

Das NP, Kumar A, Singh PK (2015) Cyanobacteria, pesticides and rice interaction. Biodivers Conserv. doi: $10.1007 / \mathrm{s} 10531-015-0886-8$

de los Ríos A, Ascaso C, Wierzchos J, Vincent WF, Quesada A (2015) Microstructure and cyanobacterial composition of microbial mats from the High Arctic. Biodivers Conserv. doi:10.1007/s10531-015-0907-7

Díez B, Ininbergs K (2014) Ecological importance of cyanobacteria. In: Sharma NK, Rai AK, Stal LJ (eds) Cyanobacteria: an economic perspective. Wiley, Chichester. doi:10.1002/9781118402238

Dvořák P, Poulíčková A, Hašler P, Belli M, Casamatta DA, Papini A (2015) Species concepts and speciation factors in cyanobacteria, with connection to the problems of diversity and classification. Biodivers Conserv. doi:10.1007/s10531-015-0888-6

Filstrup CT, Hillebrand H, Heathcote AJ, Harpole WS, Downing JA (2014) Cyanobacteria dominance influences resource use efficiency and community turnover in phytoplankton and zooplankton communities. Ecol Lett 17:464-474 
Garcia-Pichel F, Benlap J, Neuer S, Schanz F (2003) Estimates of global cyanobacterial biomass and its distribution. Algol Stud 109:213-227

Hauer T, Mühlsteinová R, Bohunická M, Kaštovský J, Mareš J (2015) Diversity of cyanobacteria on rock surfaces. Biodivers Conserv. doi:10.1007/s10531-015-0890-Z

Hense I, Meier HEM, Sonntag S (2013) Projected climate change impact on Baltic Sea cyanobacteria. Clim Change 119:391-406

Imhoff JF (2014) International Committee on Systematics of Prokaryotes, Subcommittee on the taxonomy of phototrophic bacteria, Minutes of the closed online meeting, 10-30 June 2014. Int J Syst Evol Microbiol 64:3910-3912

Kleinteich J, Wood SA, Kupper FC, Camacho A, Quesada A, Frickey T, Dietrich DR (2012) Temperaturerelated changes in polar cyanobacterial mat diversity and toxin production. Nat Clim Change 2:356-360

Makhalanyane TP, Valverde A, Velázquez D, Gunnigle E, van Goethem MW, Quesada A, Cowan DA (2015) Cyanobacteria in soils, permafrost, aquatic and cryptic polar habitats. Biodivers Conserv. doi:10.1007/s10531-015-0902-z

Mateo P, Leganés F, Perona E, Loza V, Piñas FF (2015) Cyanobacteria as bioindicators and bioreporters of environmental analysis in aquatic ecosystems. Biodivers Conserv. doi:10.1007/s10531-015-0903-y

Mitsui A, Kumazawa S, Takahashi H, Cao S, Arai T (1986) Strategy by which nitrogen-fixing unicellular cyanobacteria grow photoautotrophically. Nature 323:720-722

Nabout JC, da Silva Rocha B, Carneiro FM, Sant'Anna CL (2013) How many species of Cyanobacteria are there? Using a discovery curve to predict the species number. Biodivers Conserv 22:2907-2918

Oren A (2015) Cyanobacteria in hypersaline environments: biodiversity and physiological properties. Biodivers Conserv. doi:10.1007/s10531-015-0882-z

Oren A, Garrity GM (2014) Proposal to change General Consideration 5 and Principle 2 of the International Code of Nomenclature of Prokaryotes. Int J Syst Evol Microbiol 64:309-310

Paerl HW, Otten TG (2013) Harmful cyanobacterial blooms: causes, consequences, and controls. Microb Ecol 65:995-1010

Paerl HW, Paul VJ (2012) Climate change: links to global expansion of harmful cyanobacteria. Water Res 46:1349-1363

Palinska K, Surosz W (2014) Taxonomy of cyanobacteria: a contribution to consensus approach. Hydrobiologia 740:1-11

Pinevich AV (2008) Paradoxes of biodiversity, phylogeny, and taxonomy of cyanobacteria. Mosc Univ Biol Sci Bull 63:21-24

Pinevich AV (2014) Proposal to consistently apply the International Code of Nomenclature of Prokaryotes (ICNP) to names of the oxygenic photosynthetic bacteria (cyanobacteria), including those validly published under the International Code of Botanical Nomenclature (ICBN)/International Code of Nomenclature for algae. Int J Syst Evol Microbiol. doi:10.1099/ijs.0.000034

Posch T, Köster O, Salcher MM, Pernthaler J (2012) Harmful filamentous cyanobacteria favoured by reduced water turnover with lake warming. Nat Clim Change 2:809-813

Rejmankova E, Komarek J, Komarkova J (2004) Cyanobacteria: a neglected component of biodiversity: patterns of species diversity in inland marshes of northern Belize (Central America). Divers Distrib 10:189-199

Rikkinen J (2015) Cyanolichens. Biodivers Conserv. doi:10.1007/s10531-015-0906-8

Sciuto K, Moro I (2015) Cyanobacteria: the bright and dark sides of a charming group. Biodivers Conserv. doi:10.1007/s10531-015-0898-4

Sharma NK (2015) From natural to human-impacted ecosystems: rationale to investigate the impact of urbanization on cyanobacterial diversity in soils. Biodivers Conserv. doi:10.1007/s10531-015-0897-5

Stall M, Meysman FJR, Stal LJ (2003) Temperature excludes $\mathrm{N}_{2}$-fixing heterocystous cyanobacteria in the tropical oceans. Nature 425:504-507

Sukenik A, Quesada A, Salmaso N (2015) Global expansion of toxic and non-toxic cyanobacteria-effect on ecosystem functioning. Biodivers Conserv. doi:10.1007/s10531-015-0905-9

Wagner C, Adrian R (2009) Cyanobacteria dominance: quantifying the effects of climate change. Limnol Oceanogr 54:2460-2468

Whitton BA (2012) Ecology of Cyanobacteria II: Their Diversity in Space and Time. Springer, Dordrecht 